\title{
PEDAGOGY
}

\section{CRITERIA AND SELECTION PROCEDURE OF VIDEO MATERIALS FOR BUILDING PRE-SERVICE FOOD TECHNOLOGISTS' SPEECH PRODUCTION COMPETENCE}

\author{
Anna Boyko \\ Ukraine, Kyiv, National University of Food Technologies
}

DOI: https://doi.org/10.31435/rsglobal_ws/28022020/6934

\section{ARTICLE INFO}

Received: 17 December 2019

Accepted: 13 February 2020

Published: 28 February 2020

\section{KEYWORDS}

pre-service food technologist's, criteria selection, video materials, quality criteria, quantity criteria, speech production competence.

\begin{abstract}
The article describes the process of video materials' criteria selection for building pre-service food technologist's speech production competence and the procedure of video materials selection according to these criteria. The article defines the definition of selection criteria and determines factors were considered in the process of video materials' selection criteria specification.
\end{abstract}

Citation: Anna Boyko. (2020) Criteria and Selection Procedure of Video Materials for Building PreService Food Technologists' Speech Production Competence. World Science. 2(54), Vol.2. doi: 10.31435/rsglobal_ws/28022020/6934

Copyright: (C) 2020 Anna Boyko. This is an open-access article distributed under the terms of the Creative Commons Attribution License (CC BY). The use, distribution or reproduction in other forums is permitted, provided the original author(s) or licensor are credited and that the original publication in this journal is cited, in accordance with accepted academic practice. No use, distribution or reproduction is permitted which does not comply with these terms.

Introduction. Successful building pre-service food technologist's speech production competence needs solution of educational materials' selection problem.

M. V. Liakhovytskyi consids video and audio materials to be the most effective learning tool. According to scientist, video and audio materials' using in the educational process promotes artificial foreign language environment creation, visualization principle realization, individualization of education, intensification of speech production and increases duration of foreign language lessons. Video and audio materials are the standard of foreign language [9].

The problems of methodological potential and selection criteria of video and audio materials for speech production competence building was researched by a great number of the scholars. We can highlight such researches:

- video materials using for speech production competence building in the intensive course at the primary stage of linguistic university (N. F. Borysko);

- authentic video materials using for building pre-service lawyer's speech -production competence (S. E. Kirzhner);

- authentic feature films using for building speech production for linguistic students (V. S. Pashchuk)

- professional authentic audio texts using for building speech production for students of physical and mathematical faculties (N. R. Petranhovska).

Since the problem of video materials using for building pre-service food technologist's speech production competence in the process of independent learning is unsolved, the purpose of the article is the determination of video material selection criteria for educational goals. 
Research results. Borysko opined that selection criteria are the characteristics on the base of that quality and quantity evaluation of video materials is carried out with the goal of the inclusion or non-inclusion in educational process [2].

According to Litvin and Byriuk such factors were considered in the process of video materials' selection criteria specification for building pre-service food technologist's speech production competence $[8,1]$ :

1) methodological requirements to the content and form of educational texts and audio texts;

2) the purpose of education is building pre-service food technologist's speech production competence;

3) requirements of the food technology curriculum to:

a) the level of speech production competence;

b) the content of topics.

4) the conditions of education organization: independent learning with Moodle using.

The summarizing of scientific researches devoted to the problem of video and audio selection criteria specification for building speech production competence $[9,2,5,14,8]$ and taking into account the observations of Borysko, Krapchatova and Litvin (2010) which consider selection criteria in both quality and quantity aspects $[2,6,8]$ let extrapolate them to our problem:

I. Quality criteria:

1. Authenticity.

2. Suitability to topic.

3. Informativity.

4. Normativity and relatively correctness.

5. Intelligibility.

II. Quantity criteria:

1. Duration of video recording.

2. Rate of speech.

Authenticity is one of the most important criteria. Khalieieva consider texts created by native speakers for native speakers namely for real life, not for educational purpose to be authentic [17]. Godis defines authentic texts as texts taken from the real life of the other country (radio- or TV program, Internet) and integrated into the educational process without any changes. The scholar opined that such texts should be used for the lessons in foreign language for specific purposes [18].

According to the suitability to topic criterion, educational video materials should be in accordance with the topic content charged by Curricula in foreign language for specific purposes for pre-service food technologists. Therefore, on the base of the curricula video materials were selected to such topics:

Bread and confectionary production;

Milk processing;

Meat processing.

In accordance with informatively criterion, it is necessary to select video materials which contain efficiently professional information [10], namely messages about food technologies and their description.

According to Kirzhner normativity and relatively correctness criterion can be defined as such video materials where speech of communication participants meets the phonetic, grammar and lexical norms [5].

Sivachenko opened that the criterion of video material intelligibility is complex and contains a number of components that can be divided into two categories:

1) Intelligibility of language tools;

2) Intelligibility of sound design [15]. These categories should be described in detail.

1. Intelligibility of language tools is determined by curricula requirements. Necessary grammar and professional vocabulary to every topic should be studied by students during practical lessons.

2. Intelligibility of video sound design are determined by Kulish by such parameters for the characteristics of speech sound design: 1) diction; 2) expression; 3) emotionalism; 4) loudness; 5) accentuation; 6) voice height; 7) voice timbre; 8) tone; 9) speech defects [7]. The idea of Sivachenko can be supported that for educational purposes audio and video materials with clear diction should be selected [15].

After describing of quality criteria selection, quantity criteria should be described.

So, because of curricula in "Foreign languages for specific purposes" for pre-service food technologists does not contain the requirements to video recording duration, the number of scientific researches were studied. 
Table 1. Duration of educational video or audio recording

\begin{tabular}{|l|l|}
\hline \multicolumn{1}{|c|}{ Scholar } & \multicolumn{1}{c|}{ Recording duration } \\
\hline Tarnopolskyi, O. B. [16] & $\begin{array}{l}\text { Beginner from 2 to 3 min., } \\
\text { Advanced from 15 to 20 min. }\end{array}$ \\
\hline Krapchatova, Ya. A. [6] & $\begin{array}{l}\text { I year- from 2 min to 6 min. } \\
\text { II year from 3 min to 7 min. }\end{array}$ \\
\hline Jordan, R. R. [19] & $\begin{array}{l}\text { Beginner from min to 10 min. } \\
\text { Advanced 30 min. }\end{array}$ \\
\hline Novohradska-Morska N. A. [11] & From 1, 5 min. to 4 min. \\
\hline
\end{tabular}

The table shows that there are different views on the issue. So, the author's experience in foreign language teaching in non-linguistic university let support the opinion of Petranhovska, that reduction of foreign language lessons and the low level of food technology students' obstructs using of authentic video in full instead the scholar proposes completed in content fragments of authentic video [14]. For this reason duration of educational video recording from 1, 5-2 to 3-5 minutes is optimal for technical students [12].

Criterion of speech rate is important quantity criterion. Ivanova and Tarasova opined that speed rate of speech creates barrier for perception of information enough by first-year student at philological faculties and propose using of video materials with medium speech rate [4]. This requirement is the more relevant in the process of studying of students at engineering faculties.

The table 2 shows the selection procedure of video material for building pre-service food technologist's speech production competence.

Table 2. The procedure of video footage selection for building pre-service food technologist's speech production competence

\begin{tabular}{|c|c|c|c|c|c|c|c|c|}
\hline Criteria & 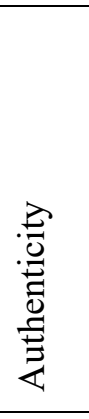 & 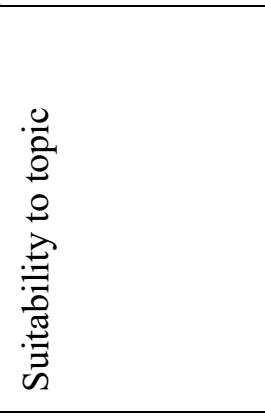 & 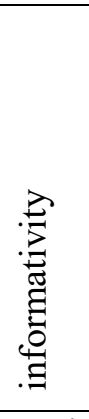 & 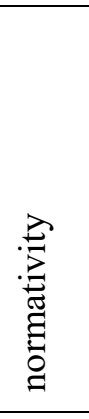 & 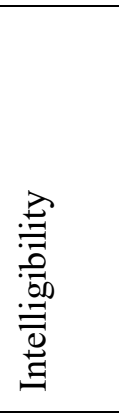 & 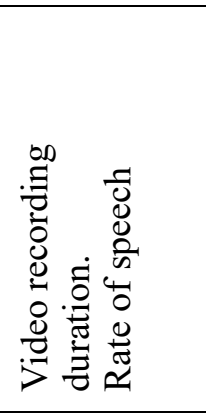 & .0 & 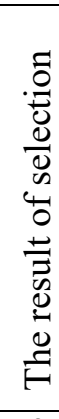 \\
\hline 1 & 2 & 3 & 4 & 5 & 6 & 7 & 8 & 9 \\
\hline $\begin{array}{l}\text { 1.The } \\
\text { industrial } \\
\text { Bread } \\
\text { Process }\end{array}$ & + & Bread Making & + & + & + & $\begin{array}{l}10 \text { min., } \\
\text { medium }\end{array}$ & + & + \\
\hline $\begin{array}{l}\text { 2.Baked } \\
\text { Bread }\end{array}$ & + & Bread Making & + & + & + & $\begin{array}{l}4 \text { min., low/ } \\
\text { medium }\end{array}$ & - & - \\
\hline $\begin{array}{l}\text { 3.Basic Steps } \\
\text { of Bread } \\
\text { Making }\end{array}$ & + & Bread Making & + & + & + & $\begin{array}{l}39 \text { min., } \\
\text { medium }\end{array}$ & + & - \\
\hline $\begin{array}{l}\text { 4.Milk } \\
\text { Chocolate }\end{array}$ & + & Confectionary & + & + & + & $\begin{array}{l}5 \text { min., } \\
\text { medium }\end{array}$ & + & + \\
\hline $\begin{array}{l}\text { 5.Mars } \\
\text { makes } \\
\text { M\&M's }\end{array}$ & + & Confectionary & + & + & + & $\begin{array}{l}1 \text { min. } 30 \mathrm{~s} \text {, } \\
\text { medium }\end{array}$ & + & + \\
\hline $\begin{array}{l}\text { 6.Old } \\
\text { Hershey's } \\
\text { Chocolate }\end{array}$ & + & Confectionary & + & + & + & $\begin{array}{l}28 \text { min., } \\
\text { medium }\end{array}$ & + & - \\
\hline $\begin{array}{l}\text { 7.Hy-Vee } \\
\text { Cheese } \\
\text { Making } \\
\text { Trip to } \\
\text { Wisconsin } \\
\end{array}$ & + & Milk Processing & $+1-$ & + & $+1-$ & $\begin{array}{l}5 \text { min. } 40 \mathrm{~s} \text {, } \\
\text { medium }\end{array}$ & - & - \\
\hline
\end{tabular}


Continuation of table 2.

\begin{tabular}{|c|c|c|c|c|c|c|c|c|}
\hline 1 & 2 & 3 & 4 & 5 & 6 & 7 & 8 & 9 \\
\hline $\begin{array}{l}\text { 8.The Art of } \\
\text { Cheese- } \\
\text { making }\end{array}$ & + & Milk Processing & + & + & + & $\begin{array}{l}11 \min 40 \mathrm{~s} \text {, } \\
\text { medium }\end{array}$ & + & + \\
\hline $\begin{array}{l}\text { 9.Cheese } \\
\text { Making in } \\
\text { the Swiss } \\
\text { Alp }\end{array}$ & + & Milk Processing & + & - & + & $\begin{array}{l}21 \text { min., } \\
\text { medium }\end{array}$ & + & - \\
\hline $\begin{array}{l}\text { 10.Widmer's } \\
\text { Cheese } \\
\text { Cellar }\end{array}$ & + & $+1-$ & - & + & + & $\begin{array}{l}9 \text { min. } 30 \mathrm{~s} \text {, } \\
\text { medium }\end{array}$ & - & - \\
\hline $\begin{array}{l}11 . \text { Food } \\
\text { processing } \\
\text { and } \\
\text { Packaging } \\
\text { Machine } \\
\text { exhibition }\end{array}$ & + & $\begin{array}{l}\text { Packaging } \\
\text { Machines } \\
\text { - }\end{array}$ & + & - & - & 30 min. & - & - \\
\hline $\begin{array}{l}\text { 12.How it's } \\
\text { Made. } \\
\text { Mozzarella } \\
\text { Cheese } \\
\end{array}$ & + & Milk Processing & + & + & + & $\begin{array}{l}4 \text { min. } 20 \mathrm{~s} \text {, } \\
\text { medium }\end{array}$ & + & + \\
\hline $\begin{array}{l}\text { 13. Sausages } \\
\text { you need to } \\
\text { know }\end{array}$ & + & Meat Processing & + & + & $+/-$ & $\begin{array}{l}1 \text { min. } 47 \mathrm{~s} \text {, } \\
\text { medium }\end{array}$ & - & \\
\hline $\begin{array}{l}\text { 14.How it's } \\
\text { made - hot } \\
\text { dog }\end{array}$ & + & Meat Processing & + & + & + & $\begin{array}{l}5 \text { min. } 02 \mathrm{~s} \text {, } \\
\text { medium }\end{array}$ & + & + \\
\hline $\begin{array}{l}15 . \text { How } \\
\text { ham is made } \\
\text { from a } \\
\text { whole pig }\end{array}$ & + & Meat Processing & + & - & - & $\begin{array}{l}7 \text { min. 14 s, } \\
\text { вище high }\end{array}$ & - & - \\
\hline $\begin{array}{l}\text { 16. Meyn } \\
\text { Food } \\
\text { Processing } \\
\text { Technology }\end{array}$ & + & Meat Processing & + & + & + & $\begin{array}{l}1 \text { min. } 14 \mathrm{~s} \text {, } \\
\text { medium }\end{array}$ & + & + \\
\hline
\end{tabular}

So, in the process of research 16 video (duration 3 hours 5 minutes) were analyzed and 7 video (duration 48 minutes) were selected.

Conclusions. Video material selection criteria for building pre-service food technologist's speech production competence were determined. These are quality criteria (authenticity, suitability to topic, informativity, normativity and relatively correctness, intelligibility) and quantity criteria (duration of video recording, rate of speech). The set of video materials was selected according to these criteria. Selected video materials will be used for creation of the subsystem of exercises for building pre-service food technologist's speech production competence.

\section{REFERENCES}

1. Бирюк О. В. Критерії відбору автентичних англомовних публіцистичних текстів для формування у майбутніх учителів соціокультурної компетенції у процесі читання . 2005. 8: 150 - 157.

2. Бориско Н. Ф. Теоретические основы создания учебно-методических комплексов для языковой межкультурной подготовки учителей иностранных языков (на материале интенсивного обучения иностранным языкам): дис. ... доктора пед. наук: 13.00.02 / Наталья Федоровна Бориско. - К., 2000. 508.

3. Бочкарьова О. Ю. Критерії відбору автентичних аудіотекстів для навчання майбутніх учителів англомовного професійно спрямованого аудіювання. Вісник Київського національного лінгвістичного університету. Серія «Педагогіка та психологія». 2006. 11: 33 - 40.

4. Іванова О.В., Тарасова В.В. Практичний курс основної іноземної мови: Learning English Through Video. Навчальний посібник. - К., 2015. 400.

5. Кіржнер С.Е. Навчання майбутніх юристів професійного англійського монологічного мовлення 3 використанням автентичної відеофонограми: дис. ... канд. пед. наук: 13.00.02 / С.Е. Кіржнер; К., 2009. 263. 
6. Крапчатова Я. А. (2014). Методика організації само- і взаємоконтролю рівня сформованості англомовної компетенції в аудіюванні майбутніх філологів: дис. ... канд. пед. наук: 13.00.02 / Я. А. Крапчатова; К., 2014. 265.

7. Кулиш Л. Ю. Психо-лингвистические аспекты восприятия устной иноязычной речи. - К.,1982. 206.

8. Літвін І. М. Відбр текстів-інтерв'ю для формування анг ломовної компетенції у майбутніх учителів. Вісник КНЛУ. 2010. 18: 176-183.

9. Ляховицкий М. В. Применение звукозаписи в обучении иностранным языкам. - М., 1979. 133.

10. Несин Ю.М. Навчання майбутніх офіцерів професійно спрямованого монологу- міркування на основі англомовних фахових автентичних аудіотекстів: автореф. дис. ... канд. пед. наук: 13.00.02/ Ю.М. Несин; К., 2013. 297.

11. Новоградська-Морська Н. А. Відбір англомовної телевізійної інформації для навчання аудіювання студентів економічних спеціальностей. Вісник Київського національного лінгвістичного університету. Серія “Педагогіка та психологія". 2005. 8: 133-139.

12. Онисина И. С. Обучение студентов технических вузов аудированию профессионально направленной речи (III этап, английский язык): дис. ... кандидата пед. наук: 13.00.02 / Ирина Сергеевна Онисина - К., 1990. 211.

13. Пащук В. С. Навчання студентів мовних спеціальностей усного англійського монологічного мовлення $з$ використанням автентичних художніх фільмів: дис. ... канд. пед. наук: 13.00 .02 / Вікторія Степанівна Пащук. К., 2002. 247.

14. Петранговська Н. Р. Навчання студентів фізико-математичних факультетів професійно спрямованого монологу-міркування на основі англомовних фахових автентичних аудіотекстів: дис. ... кандидата пед. наук: 13.00.02 / Наталія Романівна Петранговська. - К., 2004. 290.

15. Сіваченко О. О. Навчання аудіювання англомовних драматичних творів студентів старших курсів мовних спеціальностей: дис. ... канд. пед. наук: 13.00.02 / Сіваченко Олена Олександрівна. К., 2009. 284.

16. Тарнопольський О. Б. Методика навчання іншомовної мовленнєвої діяльності у вищому мовному закладі освіти: [навч. посіб.] / Олег Борисович Тарнопольський. - К., 2006. 248.

17. Халеева И. И. Основы теории обучения пониманию иноязычной речи. М.: Высшая школа. 1989. 238.

18. Godis, Tomas Produktive und rezeptive Fertigkeiten. Teil 1 Lesen und Hören. Trnave: Trnavska universita. 2016. 96.

19. Jordan R. R. English for Academic Purposes: Guide and Resource Book for Teachers. R. R. Jordan. Cambridge, 1997. 404. 